\title{
トレーシング回路・海馬連合モデルと 培養下で自己組織化されたニューロン回路網
}

東京都神経科学総合研究所 黒田 洋一郎

memory / hippocampus / neuronal network / association / self - organization

\section{I 、はじめに}

「なぜヒトでは一回しか経験しない事柄でも長期に 記憶できるのか.」という疑問に端を発し，筆者はト レーシング回路モデルを提唱し1)，シナプスに可塑的 変化をもたらす基本情報として，そのシナプスを通る インパルスの頻度（より厳密には時系列のパターン） が重要であることを本誌に述べた2). しかしながら， 大脳皮質連合野にあるトレーシング回路の重要性を述 ベた反面，従来からヒト記憶に重要であると考えられ ている海馬の役割については, Milner らが臨床例か ら結論した強化 (consolidation) 機能が, 皮質一海馬 間の閉回路結合を考えると容易に説明できることを示 したに止まっていた。

ここでは，更に考えをすすめ，最近実験的に明らか になった海馬の長軸方向の機能的連絡をもとに，連合 野のトレーシング回路は海馬を介して迅速に連合を行 うという，記憶のトレーシング回路・海馬連合モデ ル゙)提唱し，ま゙たその実験的アプローチの一つとし て試みている培養・中枢ニューロン間のシナプス形成 によってできたニューロン回路網の性質について述べ る.

\section{II．トレーシング回路・海馬連合モデル}

\section{1. 記憶における海馬の役割}

ヒト脳のもつ記憶機能で重要なのは, 複数の情報が 同時に入ってきたとき，その複数の情報の関連をコー ドする連合 (association) 機能である.たとえば，あ る人の顔と名前を覚えるように，視覚・聴覚といった 異なったモダリティーをもつ情報の間でも連合は形成

Association of "tracing circuits" by the hippocampus : self - organized neuronal network in .culture.

Yoichiro KURODA.

Tokyo Metroplolitan Institute for Neuroscience, Department of Molecular and Cellular Neurobioeogy
される、このような連合は現在まで，一般に脳の大脳 皮質の高次連合野間で形成されるものと漠然と考えら れてきた.しかし，後述される H.M. の記憶障害でも みられるように，空間的に遠く離れた場所に局在して いる，視覚情報を処理するニューロン回路と聴覚情報 を処理するニューロン回路が皮質一皮質間連絡で確実 に連絡し，かつ常に，長期に固定化されるのはかなり 困難であろう.「トレーシング回路が脳内のどこに形 成されるか」という疑問を考えていた過程で，(1)大脳 皮質と海馬の間には海馬傍回を介した両方向性の投射 がある. (2)海馬のニューロン回路は, 実は，3次元マ トリックスをなしている，という報告に基づき，ヒト 記憶における海馬の役割を考えなおしてみた。

海馬がヒトの陳述記憶に重要であるという考えは, 両側性に海馬とその周辺を切除されたてんかん患者,

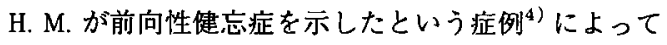
強く示唆された。最近でもこのような症例は報告され

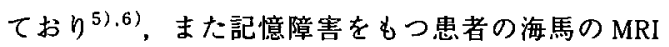
画像に異常が発見されている7).

しかしH. M. の有名人の顔の再認テストの結果によ れば，H. M. は1953年の手術後有名になった人の顔写 真を見て，一部はその名前を正確に言うことができ， しかも「この人は大統領である」といったヒントを与 えれば，ほとんど正答できだ)のである。この結果は， 「海馬は陳述記憶一般に必須の場所である」という考 えを否定している. 手術後でも一部の記憶はおそらく H. M. の大脳皮質にできた特定のニューロン回路に保 存され、しかも, 海馬がなくなっても，H. M. は有名 人の顔と名前のように，繰り返し，同時に呈示される

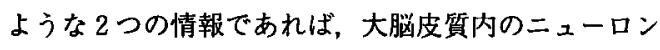
回路間に弱いながらも連合を形成し，ヒントの助けが あれば正しく検索・想起できるらしい.したがって， 「海馬は皮質の記憶眝蔵場所のIndexを蕃えており， それに基づき検索・想起を行う」という考えは、一般 的には正しくない. 
筆者は扔そらく H. M.に欠けているのは，「1 回の 呈示でも確実に長期記憶でき，連合が形成できるよう な, 海馬経由の記憶強化・連合機能」と推論した.す ると H. M. が手術後示した遅延見本合わせや, 遅延対 刺激比較テストの障害はこれらの機能の障害として理 解できる.また，「担当医の名前を覚えられない」と いった日常生活上の健忘症状は，一般に医者の名前は， 最初に会った時しか顔と同時に呈示されず，海馬を 失った H. M. は 1 回しか同時に呈示されないものの関 係を問われても連合の强化が十分行われず，すぐには 答えられなかったためと説明可能である。また, ヒト ばかりではなくサルの逰延非見本合わせ課題でも，対 象と提示位置を同時に記憶する、すなわち連合をテス トすると, サルの海馬切除が再学習を特異的に阻害す るという Mishkin の報告9)もある.

\section{2. 海馬の3次元マトリックス・ニューロン結合}

最近明らかになってきた海馬内外のニューロン回路 構造と機能のデータは図1のような海馬の強化・連合 機能モデルを示唆している，まず，海馬と大脳皮質に は海馬傍回を介した雨方向性の投射があるという報 告 $^{(0)}$ は, 大脳皮質にある記憶ニューロン回路のト レーシングをより延長し，長期記憶へのシナブス変化 を促進し，記憶の強化メカニズムの実態となる. しか も，海馬の中での主なニューロンから CAlニューロ ンへの投射は，通常の海馬切除作製に用いられる数百 $\mu \mathrm{m}$ の厚さで長軸方向に垂直に輸切りにした切片中で はあまり起こっておらず, 長軸方向のほぼ全長にわ たった他のCA1 ニューロン群の樹状突起に対して行 われていることが Ishizuka らにより報告されだ1).

さらに Tamamaki らの報告 ${ }^{12)}$ とあわせ, 海馬の主 要なニューロン結合は, 従来考えられていたような, 長軸に垂直な lamellar 構造ではなく, 長軸方向連合 性の結合が多い，3次元マトリックス構造（図2）を しており，図1のように海馬のある部位の CA3 から 遠く離れた部位の $\mathrm{CA} 1$ ニューロンへの直接・間接の 投射経路により，全く異なった感覚入力に上る異なっ

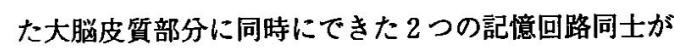
簡単に連合できることを示している，しかもこの歯状 回 $\rightarrow \mathrm{CA} 3 \rightarrow \mathrm{CA} 1$ シナブスがLTPを起こすのである

(図 2).ささらに飯島らの膜電位感受性色素を用いた 海馬長軸方向への興奮の拡がりの観察 ${ }^{33)}$ もこのよ うな長軸方向を結ぶニューロン回路が機能的にも存在 していることを支持している. 一方, 大脳皮質内でも 海馬を切除された H.M.が行ったように，呈示され た $2 つ の$ 情報の間には直接（または言語系などより高

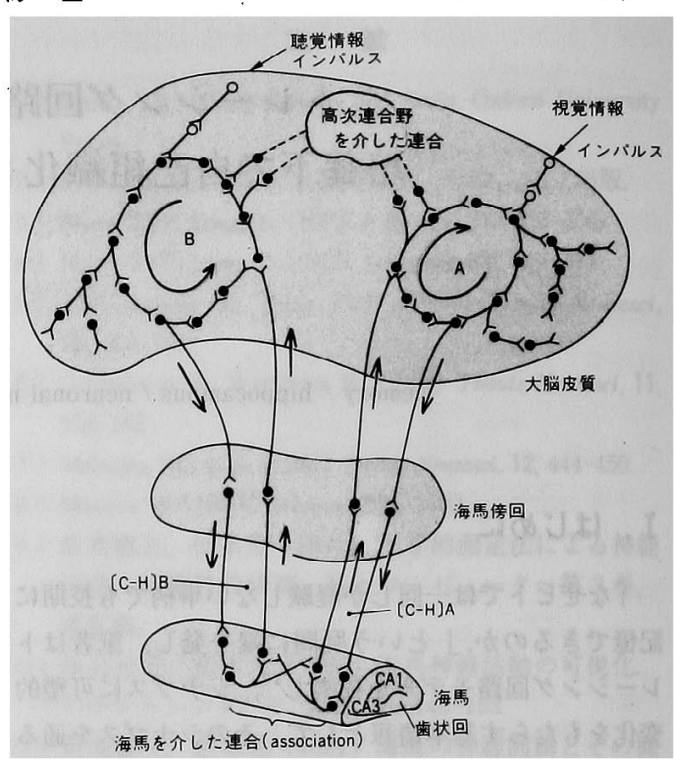

図 1．トレーシング回路・海馬連合モデル29) 異なったモタリティーをもつ感覚人力に伴うインバ ルス群（たとえば視覚と聴覚）が最終的に大脳皮質 連合野をつくり出すトレーシング回路 A, B (本来 は時間変化まで含めて 4 次元の複雑なものを極端に 単純化してある) が海馬傍回を介した両方向性の皮 澌一海馬結合による閉回路 $[\mathrm{C}-\mathrm{H}]_{\mathrm{A}},[\mathrm{C}-\mathrm{H}]_{\mathrm{B}}$ をつく ク，インパルス群によるトレーシングがより長時間 持続し, 記憶回路は強化される.ささらに皮質一海馬 閉回路に含まれる海馬 CA.3ニューロン群からの長 軸方向に広範囲な $\mathrm{CA} 1$ ニューロンへの投射により， 同時に興馠している $[\mathrm{C}-\mathrm{H}]_{\mathrm{A}}$ と $[\mathrm{C}-\mathrm{H}]_{\mathrm{B}}$ を相互に結 びつけているCA3-CA1 シナブス（Hebbian synapseにあたる) 結合はLTPなどにより強化さ れ，連合が記憶される。このシナプスが十分強化さ れている間であれば，片方のみの感覚入力により， もう一方のトレーシング回路も活性化される.

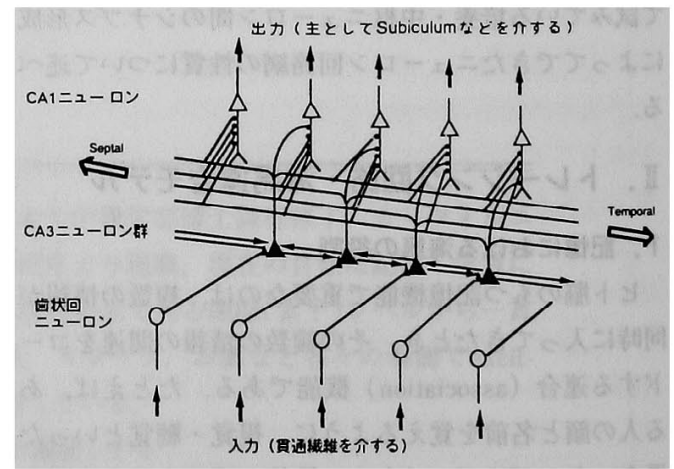

図 2. 海馬ニューロン回路網の 3 次元マトリックスモデル. $\mathrm{CA} 3$ ニューロン群から CA1 ニューロン䓳状突起へ の機能的投射は海馬長軸全体の $\frac{2}{3} \sim \frac{3}{4} に 及 ふ$. CA3 ニューロン間の連合瀻維は矢印のみに简略化してあ る.またデータの不足などの理由で貫通樴維の $\mathrm{CA} 1$ への投射など, 多くのニューロン結合を省略 してある. 
次のさまざまな情報系を介して間接的に)，連合が ゆっくりした時間の経過で形成される（図 1 ) と思わ れる．海馬における連合は，情報の集約化が起こって いるために，遅かれ早かれ消去する必要が生じる，前 編でも述べた ${ }^{2)}$ LTD や LTPの消去がその本体と思わ れるが，睡眠中にそれが起こる可能性があり, Crick の仮説 ${ }^{14)}$ はあがち䛊っていないのかもしれない.

\section{III. 培養下で自己組織化されたニューロン回 路網}

\section{1. 畄そのもののニューロンレベルでの解析の困難さ}

実際の脳で直接トレーシング回路・連合モデルを実 験的に証明または支持する為には，高い空間及び時間 分解能をもった無侵襲同時多点システムによる脳内 ニューロンの発火パターンの解析が必要である、ヒト 脳を目標に考えた場合、ニューロンレベルの解析には PET では無理で, MRI, MEGの高性能化が期待され ている段階である. 実験動物では無侵襲が必須で無い ため, 前述したような膜電位色素による大脳皮質視覚 野切片 ${ }^{15)}$ 队, 海馬切片での発火パターンの解析（本 特集・飯島論文参照) も既に行われている. 実験動物 を用いた場合，学習実験と組み合わせたときそのパラ ダイム（本当は何を見ているのか）が必ずしも明瞭で ないなど, 結果の生理的意義づけには慎重さが必要で あるが, 多くのデータの蓄積により全体像が浮かび上 がってくると思われる.

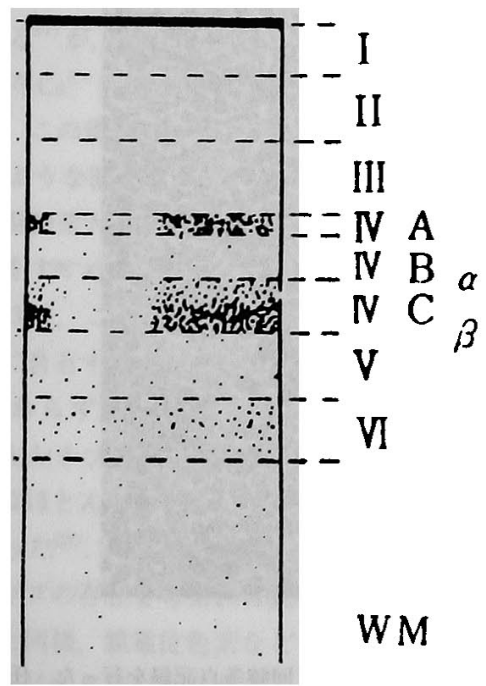

このようにヒトや動物の脳は，実際には非常に複雑 で、たとえば、ニューロンの発火パターンは観察でき たが, その結果が解析不能であることも起こり得る.

\section{2. 大脳皮質のモデュール構造}

筆者は，その意味からも，哺乳動物大脳皮質の“機 能”は非常に複雑多様であるにもかかわらず, “構造” は一定の規則と特徴を持つことに注目した. 大脳皮質 は整然とした層構造をなしており，連合野を含む新皮 質では一般に6 層をなしている（図3）。 また，それ ぞれの層に特有な二ェーロン群と, 層内, 層間のシナ プス結合が知られている。ブロードマンの脳地図にみ られるように層構造など細胞構筑の微妙な違いとほほ 対応して大まかな機能が領野 (area) としてまとまっ て存在している ${ }^{16)}$.このような脳の機能局在は古く から研究されている.さらに機能的には, 一つの領野 でも新皮質を中心に，一定の幅（約 $0.2 〜 1 \mathrm{~mm}$ ) と深 さ（Ｉ層からV層に達する）をもつカラム棈造の存 在 $^{16)}$ (図 3) が知られており,このカラム構造も連 合野を含む新皮質の多くの部分で類似した構造と機能 を持つと考えられている. すなわち、一次近似として コンピューターの素子が並んでいるように，一定の機 能を持ったニューロン集合体が整然と並んでいる可能 性が高い。このように“ある種の大脳皮質は二ューロ ン集合体を基本単位とするモデュール構造*)をなし ている”と考えられる:

しかしながら、このモデュールの構造, ことにその

*）必ずしもカラム構造と対応しているとは限らない。

图 3. 大腷皮睤の層構造とカラム構造 アカゲザルの成熟大腷皮質視覚野における6 層構造とカラム構造. ラベルしたアミノ酸を網膜に注入し、シナ ブス越え軸索輸送で運ばれた投射先の皮質ニューロン群を染め出したもの. 左, 断面図（女献30）右，表面に平衡に見た図（文献31）. 
回路網の実体（どのような種類のニューロンが，どの ようなシナプスを介して，どのように結合している か）は良くわかっていない。

\section{3. 培養大脳皮質ニューロン間のシナプス形成}

大脳皮質ニューロン群が発生の過程でどのようにシ ナプス形成を行い，どのようなニューロン回路網をつ くり上げるかは，ほとんど研究されていない。 また, 中枢ニューロン間のシナプス形成そのもののメカニズ ム、ことに関連機能分子群については未知のことが多 い.このような研究には in vitro で多数のシナブスを 形成させる条件を見いだし，機能的，形態的観察を容 易に行いうるようにし，かつ，それを定量的に解析す ることが必要だが，そのような系がいままで開発され ていなかったこここではまず筆者らが最近成功した， ラット大脳皮質ニューロン間のシナプス形成を比較的

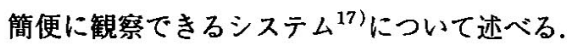

ラット（胎令18日）脳から大脳皮質をとりだし，細 胞を醉素処理で単離、培盖した。これら培養ニューロ ンの興鹪に対応する細胞内の $\mathrm{Ca}^{2+}$ 濃度の增減を fura-2を利用した細胞内 $\mathrm{Ca}^{2+}$ 濃度多点観察システム でモニターすると, 培着 3〜5日頃から蛍光強度が自 発的に增隇し，しかも培養 7 日以上たつと，ほとんど 全てのニューロンで細胞内 $\mathrm{Ca}^{2+}$ の変化が同期してい ることが観察された（図 4)。この蛍光強度の変化は テトロドトキシン (TTX) や，グルタミン酸レセプ ターのアンタゴニストである2-amino-5-phosphono valeric acid（APV) の添加により阻害された．した がって海馬ニューロン系での電気生理学的データ ${ }^{18)}$ とあわせ，大脳皮質培養ニューロン間でも，グルタミ ン酸を伝達物質とする興㽬性シナプスが多数形成され ていることが示唆された. シナプス形成をより確実に 証明するため固定包理後，電子顕微鏡による形態的観 察を行った。

in vivoで見られるようなシナプス構造が多数認め られ ${ }^{19)}, 1$ サンプル当りの観察梘野数を多くして平 均値をとることにより，形態的シナプス形成を定量化 することができた．

このような系は，シナプス形成に関与する機能分子
A

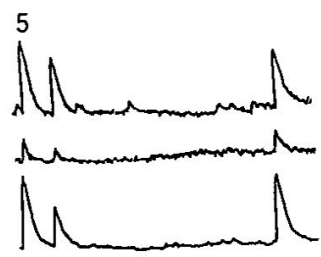

7

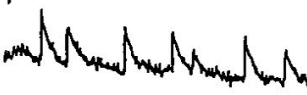
Mrenor MNMM $\|\wedge\| \|$ MMMM Nharhar

\section{B}

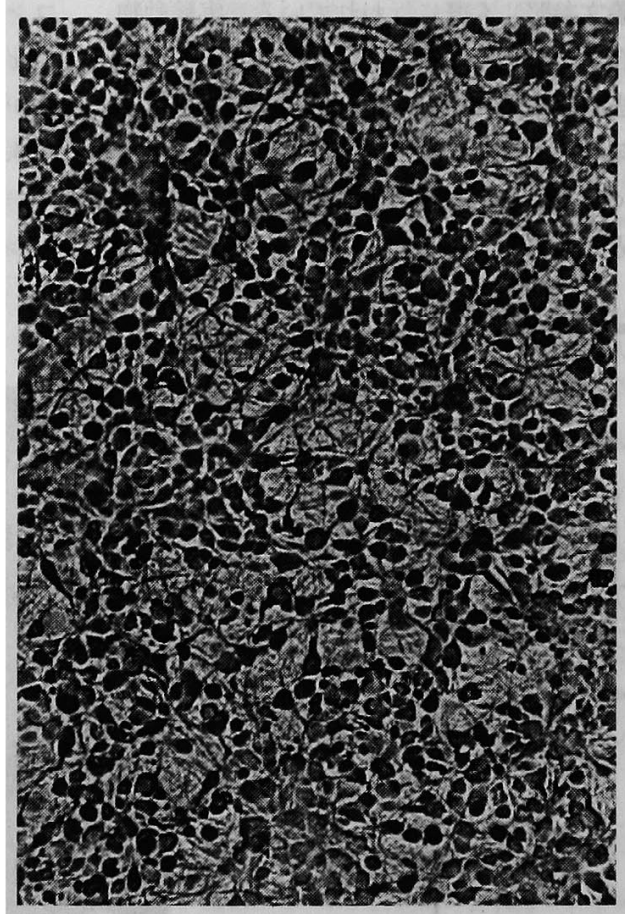

图 4. 培意ラット大脳皮質ニューロン間シナプス形成系 ${ }^{22)}$

$\mathrm{A}$ ：単離したニューロンを培窇し，5，7，9 日目に fura-2 用いた細胞内 $\mathrm{Ca}^{2+}$ 同時多点記録を行った. 任

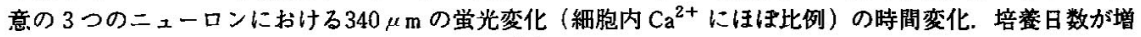
すとほとんどすべてのニューロンで同期した $\mathrm{Ca}^{2+}$ 変動がみられ，かつその周期が短くなる.

B：培盖 7 日目の位相差影微镜像. 多くのニューロン間で神経突起のネットワークが形成されている. (この 種の像だけでは実際にシナブスが形成されているかどうかはわからない) 
群のスクリーニングに最適で，すでにプロティン・キ ナーゼ阻害剂 $(\mathrm{K}-252 \mathrm{~b})$ がシナプス形成を抑制する ことから，高頻度刺激で放出されたATPを基質とし たエクト・プロティン・キナーゼによるシナプス形 成・維持の調節が示唆されている ${ }^{17), 20)}$.

一方,このような系は，II-2で述べた大脳皮質 ニューロン回路網の実体にせまる研究にも有用な可能 性がある。

\section{4. 培盖下で“自己組織化”されたニューロン回路網}

同期したニューロン内 $\mathrm{Ca}^{2+}$ の変動が, 培養ニュー ロン間で形成された多数のシナプスと自発的発火によ ることは、ほぼ確認されたが、このような現象を起こ す培養下ニューロン回路網の実体については興味深い 未知の点が多い.

第 1 にここれらのニューロン回路網に生じている自 発的発火はいくつかの特定のペース・メーカーの ニューロンの発火が, 興奮性シナプスを介して多数の 他のニューロンに伝わって生じているのであろうか.

それとも，ある種の細胞内因子の oscillation システム をほとんどすべてのニューロンがもっており，それら のニューロンが一定のシナプス結合をもつと，ある時 点から，全体として自発的な発火が見られるのであろ うか.この問題については,レーザーを使ったニュー ロン回路網の選択的破壊実験が可能なので準備中であ る.

第 2 に，形態的に固定されたシナプス数は，培養日 数とともに増加し，またシナプスの成熟・分化が観察 できる21)が，それに対応するように，スパイク状の 細胞内 $\mathrm{Ca}^{2+}$ 変動の頻度も培養日数とともに上昇して いく.この現象は, 第 1 の問題とも関連しているが, どのような回路と, $\mathrm{Ca}^{2+}$ 変動のメカニズム(ひいて は自発的発火とその停止のメカニスム) で可能なのか 研究をすすめている.

第 3 にこの培盖ニューロンの中には GABAを高 濃度に含有するニューロンがかなり含まれているにも かかわらず，拮抗剤であるビキュクリンなどで

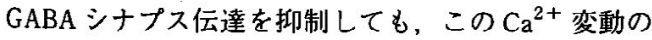
頻度はほとんど変わらないか，ときにはかえって間遠 になった23)。これは未知の抑制性伝達物質をもった シナプスの存在を考えれば説明はつくが，第 1，第 2 の点と同様，膜電位色素などをつかった実際の電気活 動の同時多点観察が必要であろう.

第 4 に, これらの培湌下二ューロン回路網は, 全体 として同期して自発的な活動を示すばかりでなく，あ る条件下では脳内カラム構造を思わす様な“島状の
ニューロン結合の集合”を形態的にもとることが見い

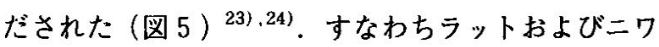
トリの大脳皮質ニューロン・シナプス形成系で，モ デュール様構造に対応すると考えられる，非同期性の 活動パターンが, いくつかの条件下で 1 つの培養ウエ ル中で見いだされた。このような in vitroで形成され たニューロン回路網のモデュール様構造は，もちろん モデル系にすぎないが，ともかく単離された皮質 ニューロンは培養条件下で“遺伝子が命じるままに” シナプス形成を行い，モデュール様構造をもった network を形成（自己組織化）するらしい.

現在，モデュール構造の出現を規定している因子に どのようなものがあるかを検索中である，さらに筆者 らの 8 年間かけて作製した中枢ニューロン表面に対す るモノクローナル抗体ライブラリー25).26)のうちには,
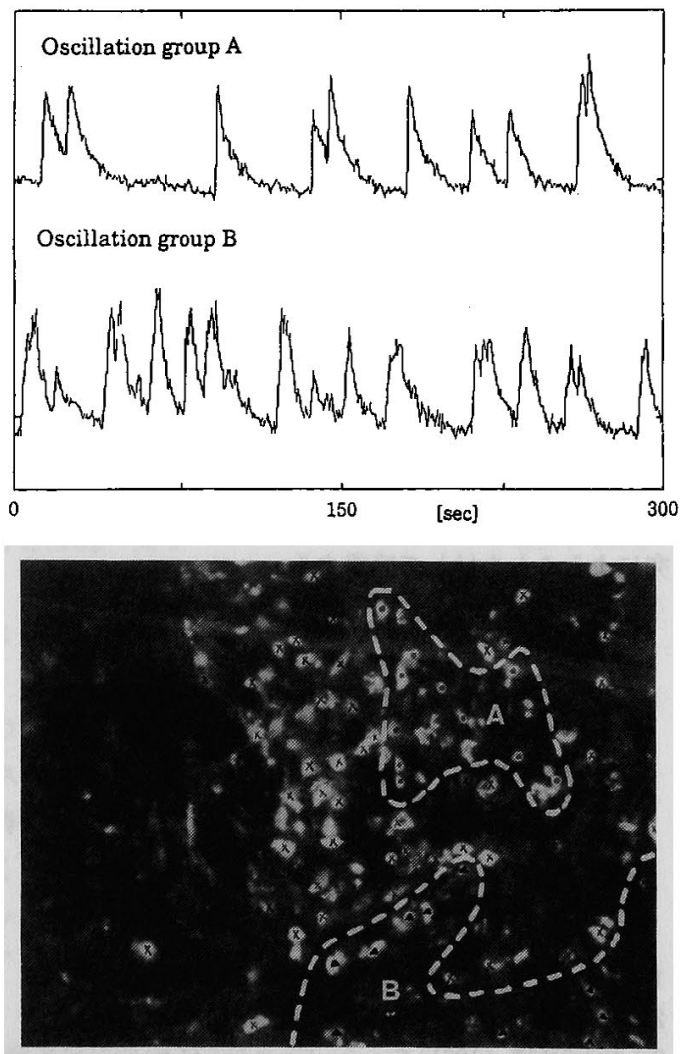

図 5．培荳ニワトリ大脳皮質ニューロン間シナプス形成系 でみられた，異なった位相のニューロン活動をもつ

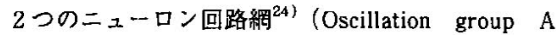
および B）上はfura-2 を用いた細胞内 $\mathrm{Ca}^{2+}$ 同時多 点記録.下はその举光顕微鏡像中の全ての二ューロ ンを同時多点記録 (group Aおよび Bの空間分布 を見たもの). 
特定の二ェーロン群と反応するものがあり、このよう な抗体を用いると実際の脳組織でのそのニューロン群 の存在様式を知ることができ，モデル系である培養系 での知見を実際の脳へ適用するための有力な武器にな ろう.

\section{N.おわりに}

実際の大脳皮質連合野のモデュール構造を，in vivoで個々の二ューロン・シナプスを識別しながら，

機能と関連させて研究するには，多数のニューロン間 のシナプス結合自体の複雑さと，入力の control の困 難さなどさまざまな障害が予想される．それらが現在 の技術でどう解決できるかが不明な現在，このような 比較的 “simple”加 “manipulation”がしやすい系 をモデル系として用いる意義は高いと考えられる，し かも，いくつかのモデュール様構造はシナプス結合に よりお互いに形態的，機能的に結合しているようで, モデュール様構造内，モデュール様構造間を分けて機 能結合を解析できる可能性がある.さらに筆者らは最 近成功したサル中枢ニューロンの培養系 ${ }^{27)}$ で，やは り大脳皮質ニューロン間シナプス形成が行われている ことを観察しており，これまで形態的，機能的に最も データの蓄積されているサルの大脳皮質での研究*) との対比がつく点でも，モデル系としての意義が高い と考えられる.

なお本稿の後半については, 東京都神経科学総合研 究所, 解剖発生学研究部門の市川真澄, 神経生化学部 門の小林和夫, 川原正博, 村本和世の諸氏との共同研 究によることを付して感謝する。

*) サルの大脳皮質の系は, 䨝長類（ヒト?）種特異的に 起こっているアルッハイマー病や，パーキンソン病, エイズなど世紀亣の神経疾患（HIV は脳ではエイズ痴 呆を起こす）の発症機序や原因究明のための研究 28$)$ に有用である。

\section{文献}

1) Kuroda, Y. (1989) Neurochem. Intem. 14, 309-319.

2 ）黑田洋一郎, (1990) 生物物理 30, 186-192.

3 ) Kuroda, Y. (1991) Soc. for Neurosci. Abst. in press.

4 ) Scoville, W. B., Milner, B. (1957) J. Neuro. Neurosurg. Psychiatry. 20, 11-21.

5 ) Zola-Morgan, S., Squire, L. A. \& Amaral, D. G. (1986) J. Neurosci. 6, 2950-2967.
6) Victor, M., Agamanolis, D. (1990) J. Cognitive Neuros ci. 2, 246-257

7 ) Squire, L. A., Amaral, D. G. \& Press. G. A. (1990) J. Neurosci. 10, 3106-3117.

8 ) Marslem-Wilson, W. D., Teuber, H. L. (1975) Neurop. sychologia, 13, 353-364.

9 ) Mishkin, M. (1978) Nature, 273, 297-299.

10) Van Hoesen, G. W. (1982) Trends in Neuroscience, 5 , $345-350$.

11) Ishizuka, N., Weber, J. \& Amaral, D. G. (1990) J. comp. Neurol. 295, 580-623.

12) Tamamaki, N., Nojyo, Y. (1991) J. comp. Neurol. 303 435-442.

13）飯島敏夫，鈴木浩文，松本元（1990）第14回日本神 経生科学学術集会, (予稿集 p.235)

14) Crick, F. (1983) Nature, 304, 111-112.

15) Tanifuji, M., Yamanaka, A. \& Toyama, K. (1990) Proc. Inter. Conference on Fuzzy Logic \& Neural Networks. 465-467.

16）有國富夫（1991）Brain Medical, 3, 147-152.

17) Muramoto, K., Kobayashi,K., Nakanishi,S., Matsuda,Y. \& Y. Kuroda, (1988) Proc. Japan Acad. Serb. 64, 319-322.

18) Ogura, A., Iijima ,T., Amano, T., Kudo, Y., (1987) Neurosci. Let. 78, 69-74.

19) Ichikawa, M., Muramoto, K., Kobayashi, K. \& Kuroda, Y. (1990) Society for Neuroscience Abstract 16, 1290.

20）黑田洋一郎 (1990) 煲白質 - 核酸 - 醭素, 35, 757-767.

21) Ichikawa, M., et al (1991) Neurosci. Res. (in press)

22) Muramoto, K., et al (1991) Brain Res. (投稿中)

23）黑田洋一郎, 村本和世, 小林和夫, 市川真澄, 第67 回日本生理学会大会 (宮崎, 1990年 4 月)

24) Kawahara. M., et al (1991) Neurosci. Let. (投稿中)

25）小林和夫,大口嘉子, 黒田洋一郎（1986）神経化学, 25, 541-543.

26) Kuroda. Y., Kobayashi, K., Ohguchi, Y. (1988) "Neuroreceptors and Signal Transduction" Plenum Press (Kito et al eds) pp 153-161.

27) Kuroda, Y., Muramoto. K., Kobayashi, K., Hirata, Y., Cho, F. \& Nagatsu T. (1990) "Basic, Clinical and Therapentic Aspects of Alzheimer's and Parkison's Disease", pp. 305 308(Nagatsu et al. eds), Plenum Press.

28）黑田洋一郎 (1990) 科学, 岩波書店, 60, 337-346

29）黑田洋一郎 (1991) Brain Medical, 3, 13-20.

30) Rakic. P. (1981) The Organization of the Cerebral Cortex. (F. O. Schmitt, et al, eds.). Cambridge, MA: MIT Press, pp. 7-28.

31) LeVay, S., T. N. Wiesel, and D. H. Hubel (1981). The Organization of the Cerebral Cortex. (F. O. Schmitt, et al, eds.). Cambridge, MA: MIT Press, pp. 29-46. 


\section{くろだ よういちろう}

昭和 41 年東京大学農学部農芸化学科卒, 46 年まで応用微生物研究所にて分 子遺伝学を専攻, 同年ロンドン大学精神医学研究所に留学, 神経生化学に転 向, 48年加現職. ヒ卜記憶の分子神経生物学を目指している. 趣味は, 野 鳥など自然観察，テニス，ダイビング，登山．最近忙しく山にはほとんど登 れなくなり，学生次代にお世話になった故深田久弥さんの遺志（?）をつい で、「私の世界百名山」を「ミクロスコピア」誌に連載して欲求不満を解消 している.

T183 府中市武蔵台2-6 東京都神経化学総合研究所

80423-25-3881 内線4003

\section{最近 5 年間に「生物物理」に掲載された神経関連の論文} (本特集序文に取りあげたものを除く)

\begin{tabular}{|c|c|c|c|}
\hline 井上・吉岡 & : & "神経情報の伝達とイノシトールリン脂質" & 1986年10月号 \\
\hline 藤沢 & : & “神経細胞認識機構” & 1987年 2月号 \\
\hline 倉知 & : & “アセチルコリンによる心筋カリウムチャンネル活性化の分子機構” & 1987年 6 月号 \\
\hline 中江 & : & “神経活動に伴う微少な熱産生の測定” & 1988年 8 月号 \\
\hline 早野ら & : & “心拍変動と自律神経機能” & 1988年 8月号 \\
\hline 芳賀 & : & “ムスカリン性アセチルコリンレセプターの構造と機能” & 1988年10月号 \\
\hline 中村 & : & “嗅細胞の環状ヌクレオチド感受性イオンチャンネル” & 1988年10月号 \\
\hline 末崎ら & : & “麻酔作用の分子論的メカニズム” & 1988年10月号 \\
\hline 久木田 & : & “軸索膜外表価のKイオン蓄積とその生理的役割” & 1988年 4月号 \\
\hline 曾我部ら & : & "機械受容器変換‧符号化機序におけるcampの関与" & 1989年 6 月号 \\
\hline 山本 & : & “神経突起の成長の機構と因子” & 1989年 6 月号 \\
\hline 東田 & : & “イノシトールリン脂質代謝産物による膜イオンチャンネルの制御” & 1989年 8 月号 \\
\hline 堀江・生田 & : & “年とともに硬くなる神経細胞膜” & 1989年 8 月号 \\
\hline 寺川 & : & “高速画像処理による神経生理機能の可視化” & 1990年 2月号 \\
\hline 池中ら & : & “ハチ毒MCDペプチドによるシナプス伝達効率長期增強作用” & 1990年 2月号 \\
\hline 佐藤ら & : & “味細胞における酸味及び苦味刺激情報のトランスダクション” & 1990年 2 月号 \\
\hline \multirow[t]{2}{*}{ 土井·石田 } & : & “エンケファリンの立体構造に基づく & \\
\hline & & $\mu / \delta$-オピオイドレセプターの基質特異性" & 1990年 6月号 \\
\hline 上田 & : & “麻酔剤にレセプターは存在するか?” & 1990年 8 月号 \\
\hline \multirow[t]{2}{*}{ 谷村 } & : & "エンハンサートラップ法を用いた & \\
\hline & & ショウジョウバエ神経系発生へのアプローチ" & 1990年12月号 \\
\hline 小松 & : & “サルの中枢視覚系に扔ける色の表現” & 1991年 6月号 \\
\hline
\end{tabular}

